\title{
Peircean Cosmogony's Symbolic Agapistic Self-organization as an Example of the Influence of Eastern Philosophy on Western Thinking
}

\author{
Brier, Søren
}

Document Version

Accepted author manuscript

Published in:

Progress in Biophysics \& Molecular Biology

DOI:

10.1016/j.pbiomolbio.2017.09.010

Publication date:

2017

\section{License}

CC BY-NC-ND

Citation for published version (APA):

Brier, S. (2017). Peircean Cosmogony's Symbolic Agapistic Self-organization as an Example of the Influence of Eastern Philosophy on Western Thinking. Progress in Biophysics \& Molecular Biology, (131), 92-107. https://doi.org/10.1016/j.pbiomolbio.2017.09.010

Link to publication in CBS Research Portal

\section{General rights}

Copyright and moral rights for the publications made accessible in the public portal are retained by the authors and/or other copyright owners and it is a condition of accessing publications that users recognise and abide by the legal requirements associated with these rights.

\section{Take down policy}

If you believe that this document breaches copyright please contact us (research.lib@cbs.dk) providing details, and we will remove access to the work immediately and investigate your claim.

Download date: 26. Apr. 2023 


\title{
Peircean Cosmogony's Symbolic Agapistic Self-organization as an Example of the Influence of Eastern Philosophy on Western Thinking
}

\section{Soren Brier}

\author{
Journal article (Accepted manuscript)
}

CITE: Brier, S. (2017). Peircean Cosmogony's Symbolic Agapistic Self-organization as an Example of the Influence of Eastern Philosophy on Western Thinking. Progress in Biophysics \& Molecular Biology, (131), $92-$ 107.

001: 10.1016/j.pbiomolbio.2017.09.010

Uploaded to Research@CBS: December २०18

(C) 2018. This manuscript version is made available under the CL-BY-NC-ND 4.0 license http://creativecommons.org/licenses/by-nc-nd/4.0/ 
For the Special issue on Integral Biomathics: The Necessary Conjunction of the Western and Eastern Thought Traditions for Exploring the Nature of Mind and Life of Progress in biophysics \& Molecular Biology 2017

\section{Peircean Cosmogony's Symbolic Agapistic Self-organization as an example of the influence of Eastern Philosophy on Western Thinking.}

Søren Brier, Department of Management, Society and Communication, Copenhagen Business School.

\section{Abstract:}

Charles S. Peirce developed a process philosophy featuring a non-theistic agapistic evolution from nothingness. It is an Eastern inspired alternative to the Western mechanical ontology of classical science also inspired by the American transcendentalists. Advaitism and Buddhism are the two most important Eastern philosophical traditions that encompass scientific knowledge and the idea of spontaneous evolutionary development.. This article attempts to show how Peirce's non-mechanical triadic semiotic process theory can embrace the quantum field view better than the mechanical and information views in a theory of the emergence of consciousness. Peirce views the universe as a reasoning process developing from pure potentiality to the fully ordered rational Summon Bonum. The paper compares this with John Archibald Wheeler's "It from bit" cosmogony based on quantum information science, which leads to the info-computational view of nature, mind and culture. However, it is missing a phenomenological foundation. David Chalmers' double aspect interpretation of information attempts to overcome the limitations of the info-computational view. Chalmers supplements Batesonian and Wheelerian info-computationalism -both missing a phenomenological aspect with a dimension that corresponds to the phenomenological aspect of reality. However, he does not manage to produce an integrated theory of the development of meaning and rationality. Alex Hankey's work goes some way towards establishing a theory that can satisfy Husserl's criteria for consciousness - such as a sense of being and time - but Hankey's dependence on Chalmers' theory does that it is still not able to provide what the connection between core consciousness and the physical world is.

Keywords: Cosmogony; Peircean semiotic philosophy: Cybersemiotics; info-computationalism; it-from-bit cosmogony; Philosophy of Science; Interdisciplinarity; Advaita Vedanta philosophy; Buddhist philosophy; Transcendentalists philosophy; multi-universe theory; developing laws; irreversible time; sustained criticality.

\section{Introduction}

This paper defends the idea that Charles Sanders Peirce's pragmaticist triadic semiotic agapistic cosmogony solves some fundamental problems in physics about "how come existence" as J. A. Wheeler (1994:295) formulates it, as well as addressing how experience and meaning is possible in a scientific cosmogony. These questions have conjured the deepest philosophical problems with which modern physics has struggled, as exemplified in Wheeler (1990, 1994, and 1998 , Davies (2004 and 2007), as well as Hawking and Mlodinow (2010) who claims that philosophy is dead and has nothing has to say any more about these large questions. 
Let us briefly review a selection of respected research in this area and the problems I see compared with Peirce's philosophy. Roger Penrose (1987 and 1996) is one prominent physicist and mathematician that has taken up the challenge of these questions, including a scientific quantum theory of consciousness crafted with Stuart Hameroff (Penrose and Hameroff 2011). However, Penrose and Hameroff's attempt does not seem to include a phenomenological element in its foundation or a theory of the emergence of experiential consciousness. Another famous physicist who has grappled with these questions and found it necessary to avoid a mechanical ontology is Lee Smolin (2014), who has challenged the mechanical ontology with its transcendental and absolute timeless laws. He writes: " The Cosmological questions such as Why these laws? and Why the initial conditions? cannot be answered by a method that takes the laws and initial conditions as input." (Smolin 2014: 250). But treating laws and initial conditions as input is what modern classical physics used to do and therefore Smolin's work here is quite revolutionary. Moreover, he is quite aware that the thought was foundational to Peirce's cosmogony and quotes him several places in the book with respect to the theory of the laws manifesting as the universe develops. Unger and Smolin in their book The Singular universe and the Reality of Time (Unger and Smolin 2014) further develops these thoughts attempting to start a revolution in the natural philosophy of cosmogonial thinking, but still missing a phenomenological aspect.

Hankey (2015) makes some very interesting progress in establishing a scientific model for a physiological dynamic system that could carry core consciousness experience. Core Consciousness is not only sensory experience, but the sense of self that is the basis of all sense experience. It is a pure consciousness without content and is therefore beyond any digital information explanation. As Brier (2015b) also argues then standard information theory and science are not sufficient to carry the concepts of meaning and awareness, which are both beyond any kind of information or code. This is also argued in (Brier 2015a) in a critique of Barbieri's still mechanistic code biology in the previous special issue.

I do agree with Alex Hankey's thesis that the appearance of the cosmos physically understood takes place through the information generated by wave function collapses at the quantum level in nonequilibrium thermodynamic states. Nevertheless, information is not enough (Brier 2008) unless in the info-computational view a double aspect theory is introduced giving information a Phenomenological qualia aspect as suggested by Chalmers (2010:26).

Chalmers builds his theory on a combination of Bateson's "information is a difference that makes a difference" (Bateson 1973) and Wheeler's "it-from-Bit" delayed-choice view of the selfinteracting universe (Wheeler 1994). However, no matter how much I appreciate Bateson's cybernetic information ecology I believe he is missing phenomenology in his theoretical basis (Brier 1992 and 2016). I furthermore fail to see how Wheeler's quantum physicalism, making the world a place of mutual measurements without a mind, could integrate a theory of consciousness and qualia as a parallel reality. I doubt that the dynamics of experience and meaning are the same as physical information even if that is quantum information in the form of qubits. At the very least, I need to see some arguments for it. I consider Hankey's work to be very progressive in trying to provide that. his point of departure is in Husserl's characteristics of the core qualities of consciousness: "(a) a sense of self, (b) a sense of continuing existence" (Hankey 2015:289).

I agree with Hankey in his critique of the "Tucson approach" and his arguing for a new kind of information, where coherence and criticality at the edge of chaos seems to be necessary components to establish a physiological foundation for conscious awareness. However, as long as the theories and 
models explain incoming data that are all produced in either in a physicalistic or info-computational framework alone there remains the problem of how they fit together with the qualitative aspects of reality and how they have developed in evolution. This is pretty much what Nagel (2015) - in his controversial book - is arguing when it comes to neo-Darwinian explanations of mind. I am therefore somewhat skeptical about attempts to solve the hard problem within this framework not all least, because it also lacks a theory of embodied social production of knowledge or knowing.

Although Hameroff (2017) does makes some progress here in comparison with his and Penrose's Orch-OR mathematical physicalism (Penrose and Hameroff, 2011), I do not think that he manages to set up a consistent philosophical framework explaining the emergence of mind in evolution. I do think that Deacon (2011) goes much further in taking this problem seriously by incorporating important components of a Peircean process and emptiness view as well as part of his semiotic philosophy. Yet he still encounters some of the same problems, because he is unwilling to accept the full philosophy of Peirce.

In my view, Peirce's philosophy only makes sense as a whole packet in its Architectonic nature (Brier 2014a). That applies to Stjernfelt's work (Stjernfelt 2014), too. Although it is an intriguing work of semiotic process philosophy, he is focusing only on the 1 development of the thinking process in natural, human and cultural systems and not on the sentiment and agapistic part (Brier 2015c). Both Deacon and Stjernfelt avoid the well-crafted quantum neurophysiological theory of Hameroff and Penrose (2011) in their theories. Penrose is, of course, very well aware of the limitations of the use of digital information concepts for our theories of experiential consciousness (Penrose 1989, 1994, 1997) as it is found for instance in Wolfram's "New kind of Science" (Wolfram 2002). Chalmers (2010:463), on the other hand, seems willing to accept a metaphysics that combines 1) info-computation, with 2) creation from outside the physical universe and 3) a Cartesian-like mind-body dualism hypothesis as a possible minimal framework. Evolutionary and ecological theory seems to play no significant role in his theory, and the semantics is without semiotics, as is so common in analytical philosophy. But, it is resulting in a lack of the role of sentiment and existential aspects of hermeneutics. As a result, the explanatory power of this very open metaphysics is not very great, in my view.

My hypothesis is that the problem of consciousness is hard because it is a product of unreflected ontological presumptions and it can therefore not be solved within these selfsame frames. With Peirce and Bhaskar (1975, 1979, 1999, 2000, 2002a-e), I think we need to work consciously reflected with our metaphysical assumptions. The problem I am focusing on is which kind of paradigmatic ontology of nature, culture and knowing are you going to explain or model the fact of core consciousness in humans (Brier 2008)? The present understanding of physics and big bang cosmogony combined with materialist and informational evolution theory does not seem to be sufficient. One cannot work from a phenomenological basis in a dualist ontology, as phenomenology is monistic: the experiential world is the world, which is not to be explained from something else, which is qualitatively different. This was what Merleau-Ponty (1962, 1962, and 2003) struggled with, when he recognized the necessity of an embodiment in a living system for consciousness to exist in a spacetime world and furthermore realized that the body was - in his time - only described in mechanistic natural science. Peircean biosemiotics (Favareau 2010) agrees with Hankey (2015) that the body is not a machine (Brier 2015a) or a sort of non-Turing computer processing an informational reality (Brier 2015b).

Hankey (2015) attempt to solve this deep problem by showing that the living body is not a mechanical system. Mechanical systems give fixed responses to a series of fixed stimuli, but physiological systems give the (1/f) distributions of responses and therefore do not behave like 
mechanical systems. His argument is that (1/f) distributions and associated self-organized criticality imply that physiological control systems should not be classified as mechanical systems. Therefore, the naive materialist paradigm of Descartes etc. should no longer be considered to apply to biology. That is enlightening for the understanding of the dynamics of biological systems; but it does not explain how experience is possible in non-mechanical physical systems, with the concepts of matter, laws and time we are working with now. It does not matter much if it is a classical or a quantum mechanical model. I fail to see how quantum physics be it quantum mechanics or quantum field theory in itself have any bearing in solving the mystery of the existence of experience in a physical world. It does not matter how spontaneous, non-linear, cybernetic circular causal, systemic and non-equilibrium thermodynamically self-organizing it is. Even when it is combined with close to chaos criticality as Hankey most interesting ads to the model, it does not explain the experiential aspects of reality.

\section{The evolution of consciousness in a physicalist material world?}

The deep problem in the received view of physics and biology has been that of how to connect Big Bang Cosmogony, with Neo-Darwinian evolutionary theory and explain the emergence of mind in physicalistic ontology - original a classically based, today a quantum field based framework. The inability of the Neo-Darwinian evolutionary theory to give a scientific explanation of the development from matter to mind and culture is described very well by Thomas Nagel (2013) in the book with the telling title: Mind and Cosmos: Why the Materialist Neo-Darwinian Conception of Nature Is Almost Certainly False. As Nagel is a declared atheist his alternative is therefore not the theory of intelligent design. However, his view is that:

...The prevailing doctrine - that the appearance of life from dead matter and its evolution through accidental mutation and natural selection to its present forms has involved nothing but the operation of physical law - cannot be regarded as unassailable. It is an assumption governing the scientific project rather than a well-confirmed scientific hypothesis. (Nagel 2013:11).

Ever since his famous phenomenological question in the paper 'What is it like to be a bat?' (Nagel 1974), he has been pointing to the missing phenomenological dimension of scientific explanations of the evolution of mind and consciousness; including Stephen Wolfram's (2002) new kind of Science.

Chalmers (1995 p. 201-2 and 1996) is well known for defining what he calls the easy and the hard problems of consciousness. The easy problem has to do with the inner workings of consciousness, such as the ability to discriminate, categorize, and react to environmental stimuli, to be able to report mental states by accessing internal states and be able to distinguish between them. But the hard problem, which we are dealing with here, is to explain how core consciousness, sense experiences and their different qualia emerges from physical brain and body matter understood in a naturalistic framework. How can the ability to experience emerge from, what science presumes to be a material world?

The philosopher John Searle (1980, 1989, 1997 and 2007) is famous for arguing that the hard problem is hidden in the understanding of our biology. If that is the case, then biosemioticians have for many years argued that this mystery cannot be resolved through the kind of mechanistic biology that is dominant today (Brier 2015a, Hoffmeyer 1996, 2008, Favareau 2010 ). That an informational algorithmic paradigm is also too limited is well-argued by Poznanski, Tuszynski and Feinberg (2017: xii):" Sentience refers to subjective experiences that cannot be algorithmically represented through 
reductionism even when the performance of all relevant functions is explained through algorithms". Nevertheless, in their book they continue their search within a natural scientific frame culminating with Hameroff and Penrose's attempt to integrate quantum physics and neurobiology in their Orchestrated objective reduction theory (Orch OR), on which they have worked progressively for over 20 years. It is a matter of opinion if they are on the way to solve the hard problem within the frames of modern science or not. I doubt if it the solution to this question lies within the present scientific framework's battery of concepts and theories. I share this doubt with the philosopher McGinn (2000) as exemplified in his book with the significant title: The Mysterious Flame: Conscious Minds in a Material World, which is already famous for arguing this doubt. Nagel (2013), in his conclusion, is open to McGinn's view as a possibility, without quoting him specifically. However, I agree with Faye (2016) that nevertheless we need to develop a metaphysics compatible with most of what we believe is pretty solid scientific knowledge. A non-mechanical evolutionary naturalism seems unavoidable. The problem is how it is going to explain experience and meaning or at least or include it consistently in its ontology?

I concur with McGinn and Nagel's critique and draw the consequence that we need a new ontology and scientific epistemology to solve the hard problem in an evolutionary context. Thus, if we do not believe that the brain is just a computer and that informational computation is what creates consciousness in the human body, then it must be something else. The tragedy is that biology so far has only been able to give functional definitions of life. Searle (1980) believes that the brain's production of intentionality is like chlorophyll's production of carbohydrates through photosynthesis. But experience is a qualitatively different product than carbohydrates. We can describe and measure carbohydrates scientifically, but this is not the case with the quality of experience. As far as we know today, only living bodies can produce the awareness necessary for having experience. However, the living, experiencing flesh is still a mystery to the life sciences in their present non-semiotic form (Emmeche 1998), as long as their foundation is the receive view of the physic-chemical sciences. As Favareau in his useful introduction to a spectrum of biosemiotic theories $(2010 \mathrm{p}$. vi) points out, biology rather makes the hard problem a triple problem: "What is the relation between mental experience, biological organization, and the lawlike processes of inanimate matter?"

Hankey (2015: 290), in continuing to develop the informational hypothesis, sums up the conditions for the kind of information structures needed to support experience: 1. Penrose's (1989) sufficient coherence, 2. Chalmers' (1995) none-reductiveness, 3. Baars' (1997) global workspace. Hankey argues that only when combined can they produce a structure that can support the integrated information necessary for consciousness, adding that the system also has to be non-linear. His view is that the system at criticality produces a completely new kind of information because of the long range of correlation of lower system entropy (ibid 295). It is like flow vectors with infinitesimal loops altering the vectors' direction into an unstable mixture of vector states, thence producing a new kind of information unrelated to the digital information used in computers (Ibid 296). Hankey's hypothesis is that critical feedback stabilities in cortical neural networks on the edge of chaos with cybernetic loops will be able to maximise information diversity and transform the information from an 'objective' standpoint to one that is concerned with 'subjective' experience. This demands one to view the self as process (Ibid 297) and furthermore to use Chalmers's double-aspect theory of information, which integrates information from thought, memory and perception. As such, brains will have reflective abilities and thus the biological development of the conscious brain almost explained.

The problem with this well-thought through innovative theory is that the experiential aspect is here only a philosophical speculative hypothesis of Chalmers on how the ability to experience can 
emerge from, what science presumes to be, a material world. No system that could produce awareness has ever been constructed in laboratory. Many do expect such production to occur in the merger of artificial intelligence and robotics; but, at this stage we must accept that biology cannot explain why and how we see and hear and smell the world (Edelman 2000: 222). Biology can only model the physiological way organs like the brain works; it can say nothing about how the brain actually produces experience; if that is what it does. That also goes for Hankey's theory, though he is closer to grasping the dynamical aspect of the issue than most, and then there is no real theory of the ontology of experience. The problem lies with Chalmers' theory.

Chalmers (1996) collects nearly all the material in science and philosophy we had on the subject at that time, except Peirce's semiotic philosophy. His conclusion of the book is suggesting a type of double aspect theory, where the experiential is the inside of information in the brain. Whatever that means? I do not see how viewing objectively defined information and experiential meaning as two aspects of "the same" solve the deep troublesome problem lying in the observation, that I am not my brain. How will Chalmers ontologically explain a world of experience, awareness and meaning as part of reality? Will all objective information have an inner experiential based life? If so, why and how is that possible? Furthermore, one should not commit the merological fallacy to contribute to the part that, which only makes sense when attributed to the whole. It is not the brain that experiences; it is embodied human persons in a culture with a language (Bennett and Hacker 2007, Cowley et. all 2010). The subject is not reducible to the brain. As a human self, I am rather the non-material linguisticallyinformed self-organizing autopoietic product of my embodied brain and culture? Thus, it seems that core consciousness cannot be explained form the physiological model we call "the brain" no matter how deep we go in quantum-neurophysiology! Is it then possible that conscious awareness and experience is something we are missing in our scientific explanations of living systems cognition and communication as dark matter and energy were missing in the cosmological descriptions of the universe's evolution?

Hankey argues for his theory that because "at criticality, states of material are unrecognizably transformed. ... They exhibit completely different physics from that of original stable matter." (Hankey 2015:287). This seems to demonstrate a dynamics that is similar to phenomenological consciousness and to instantiate an entirely different kind of physical theory - not the physics of stability but - the physics of instability. It is a very innovative and integrative piece of work. Nevertheless, physics still remains the terrain of argument, although Hankey seems to hope that the similarity in dynamics will indicate some kind of emergence of experiential qualities. Thus, I think that criticality, cybernetics and quantum theory in itself is not sufficient to redeem Hankey's use of Chalmers double aspect information theory.

The reason I am skeptical towards this interesting hypothesis is that Bateson's cybernetics and Wheeler's quantum physical theory both lack a phenomenological foundation in ontological and epistemological frameworks (Brier 1992, 2015a + b and 2017). Chalmers' theory seems to me to be a very hypothetical suggestion since it is not integrated in a consistent metaphysical framework like the architectural theory of Peirce (CP, 1.7-34). For Peirce, mind and matter are already connected fundamentally in his synechistic philosophy. They are different ends of the same spectrum or the same line. Peirce wrote:

Synechism, even in its less stalwart forms, can never abide dualism, properly so called. It does not wish to exterminate the conception of twoness, nor can any of these philosophic cranks who preach crusades against this or that fundamental conception find the slightest comfort in this 
doctrine. But dualism in its broadest legitimate meaning as the philosophy which performs its analyses with an axe, leaving as the ultimate elements, unrelated chunks of being, this is most hostile to synechism. In particular, the synechist will not admit that physical and psychical phenomena are entirely distinct, -- whether as belonging to different categories of substance, or as entirely separate sides of one shield, -- but will insist that all phenomena are of one character, though some are more mental and spontaneous, others more material and regular.

$$
\text { (Peirce, CP, 7. 570) }{ }^{1}
$$

Peirce is inspired by Aristotle's hylozoist $(\mathrm{CP}, 6,6)$ or hylopathic $(\mathrm{CP}, 1.24)$ view of matter as being a plenum and alive inside

One further point is that the reality of experiential and meaningful social phenomena is something qualitative different from physical reality, though they do occur within space-time. The social world of meaning and values is real and interactions in it can be described systematically, as for instance shown in Weber (1920). Biological evolution is usually not a part of social science and humanities paradigmatic framework (Cobley 2016). This is the story biosemiotics attempts to tell, since the sciences are not conceptually equipped to accept it (Emmeche 2004). Thus, we should encompass the social as well as the individual experiential reality and their history in nature. The problem is how we are going to connect them? Where to put the brain in experience and where to put experience in the world? As I have argued in Brier (2008) and many papers since then that in order to answer this question we need to construct transdisciplinary frameworks as also Nicolescu argues (Nicolescu 2002 and 2014). In the Cybersemiotic star we take departure in the knowledge produced where embodied conscious, semiotic and linguistic, communicates meaningfully in the context of culture and nature as a non-reducible whole. Knowing is neither phenomenological nor physical, biological or social reducible to something else(Brier 2008).

That is why I am willing to consider Peirce's extraordinary battery of concepts in his carefully developed process metaphysics of pragmaticist triadic semiotics, as they are constructed to give a solution to these problems, as I have argued for in Brier (2014a) and in my contributions to developing a Peircean biosemiotics (Brier 1999, 2011 and 2015a).

\section{The Peircean contribution}

Peirce's ontological and cosmogonical ideas are unusual in that they are inspired by his father Benjamin Peirce's work from 1881 on The Ideality In The Physical Sciences, as well as the Concord transcendentalists (Goodman 2015) that was inspired and lead by Ralph Waldo Emerson (1883) (Dilworth 2009). The transcendentalists worked towards a unification of science, philosophy and ethics

\footnotetext{
${ }^{1}$ I uphold the tradition of referring to Peirce's work with the following abbreviations: CP for Collected Papers (see Peirce, C. S. [1931-58]. Collected Papers.); EP for Essential Peirce (see Houser, Nathan \& Christian Kloesel (eds.)(1992). The Essential Peirce. Selected Philosophical Writings, Volume 1 (1867-1893) and Peirce Edition Project (ed.)(1998). The Essential Peirce. Selected, Philosophical Writings, Volume 2 (1893-1913)), W for Writings (see Peirce Edition Project (19822009) Writings of Charles S. Peirce: A Chronological Edition 1857--1892 Volume 1- 8. Volume number is followed by page number NEM vol. pages: Carolyn Eisele (ed., 1976), The New Elements of Mathematics by Charles S. Peirce. MS for unpublished manuscripts that are now often publish on websites like for instance Arisbe, or kept in the Houghton Library at Harvard numbers from Richard R. Robin's catalogue.
} 
in a spiritual view (Richardson 1995) that is quite close to Perennial Philosophy (Geldard2005). The view of the transcendentalists is close to the Advaita Vedantic non-dual ontology of the Indian yogic philosopher Adi Shankara (Shankara 1957, 1977 and Isayeva 1993) and Buddhism (Garfield 1995, Bishop, 1981, Siderits and Katsura, 1999, Suzuki, 1957, 1963, and 1969) of which Peirce was aware (see also Jackson 1981 for the Indian influence on Unitarian thinking). These views are all process philosophies embracing evolutionary theory, as discussed in Brier (2008).

The view of Cosmogony and evolution of living systems that we are beginning to approach here is neither a Neo-Darwinian 'blind watchmaker' materialism nor a theistic creationist view. If these two cosmogonies are seen as Hegelian thesis and antithesis the non-dual evolutionary ontology may be called an aufhebung to a new level of synthesis (Bhaskar 1999). Interestingly the British philosopher of science Roy Bhaskar from around 2000 allow his Indian background to influence the ontological aspect of his philosophy (Bhaskar 2000 and 2002 a,b,c,d,e) towards a non-dualist process view in an attempt to integrate Western philosophy of science and dialectical thinking with Eastern spiritual process thinking. Peirce's ontological view is based on an empty field of random spontaneous virtual activity manifesting as differences and habit through evolution and has, here, surprising similarities with quantum field theory's view of the vacuum field within which, at the Planck Scale of time and length, a quantum foam forms (Wheeler 1994). Peirce called his view of the function of absolute chance as spontaneity in Cosmogony for Tychism.

The evolutionary process philosophy (Kultgen 1959-60) Peirce developed, he integrating German idealism with British empiricism through his view of logic as semiotics. This is the ontology and epistemology that I believe is a more adequate framework for science to use as a foundation for solving the problem of mind in cosmogony we have raised. Contrary to his forerunners, Peirce was an empirically practicing scientist as well as a logician and a philosopher. He was exceptional in combining these three strands of his work in a very original way through his pragmaticist semiotics, the significance of which is only now becoming clearer to us, through the modern development within all three areas (Romanini and Fernández 2014).

The quantum physicist Henry Stapp (2007:19-20) explains the move from classical physics to quantum physics as a transition from an ontology of positions and momentums of inert matter represented by ordinary numbers to an ontology of ordered actions and quantized action possibilities. This is pretty close to Peirce's pragmaticism with its combination of tychism and synechism in his semiotic process philosophy. It also exceeds any type of objectivist information theory including the one Wheeler (1994) uses in his "it-from -bit" philosophy. Wheeler benefits from cybernetics' and system theories' use of the process of self-organization; but along with them, he lacks a philosophy of the process of experience and meaning as internal to particular ways of life and existential orders such that values are particular to a particular worldview. This critical point also pertains to Chalmers (2010).

Peirce never bought into the classical mechanical paradigms of physicalism and the idea of absolute objectivity because he realized that his fallibilist process view would always have to include a normative aspect. For him, the normative sciences were aesthetics, ethics and, ultimately, logic, since logic was the study of the right way to think (CP, 4. 573-577). Peirce was deeply rooted, in the intellectual inquires for shaping a self through self-control in which an ultimate value and form of life would be revealed. That is something missing from modern science. This has been, especially, the problem of classical physics. As Stapp writes:

Science is not only the enterprise of harnessing nature to serve the practical need of human kind. It is also part of man's unending search for knowledge about the universe and his place within it. 
This quest is motivated not solely by idle curiosity. Each of us, when trying to establish values upon which to base conduct, is inevitable led to the question of one's place in the greater whole. The linkage of this philosophical inquiry to the practical question of personal values is no mere intellectual abstraction.... For what we value depends on what we believe, and what we believe is strongly influenced by science. ... In that scientific vision we human beings were converted from sparks of divine creative power endowed with free will, to mechanized automata - ... This material picture of human beings erodes not only the religious roots of moral values but the entire notion of personal responsibilities... science is double culpable: It not only erodes the foundation of earlier value systems, but also acts to strip man of any vison of himself and his place in the universe that could be the rational basis for an elevated set of values... During the twenties century this morally corrosive mechanical conception of nature was found to be profound incorrect. It failed not just in the finer details, but at the fundamental core.

(Stapp 2007:4)

Peirce already saw this more than a hundred years ago.

\section{Interdisciplinary limits of modern system and cybernetic information science}

Let us go a bit deeper in the argumentation of the limits of information science when it come to the hard problem. Since Peirce's time, modern system science has been integrated with nonequilibrium thermodynamics and cybernetics, based on the modern statistical concepts of information developed by Shannon (1949) and (1963). Schrödinger (1944), especially, integrated thermodynamics and statistical information theory which, through a recent further integration with Prigogine's nonequilibrium thermodynamics (Prigogine, 1996), became a universal theory of self-organization as in The self-organizing Universe by Jantsch (1980). Now that initial integration has been further extended with the autopoiesis theory of Maturana and Varela (1980) - based on Von Foerster's (1979) secondorder cybernetics - regarding how systems obtain individual closure to that informational influence from outside that threatens to disrupt their inner organization. Stuart Kaufmann (2004), in similar vein, invented the term autonomous agent from a cognate thermodynamic analysis. Milan Zeleny (1980) quotes in his obituary for Jantsch the following vision for systems biology to solve the hard problem:

The new paradigm of self-organization, and with it the focal concept of autopoiesis, ends the alienation of science from life. It forms the backbone of an emergent science of life that includes a science of our own lives, the biological as well as the mental and the spiritual aspects, the physical as well as the social and the cultural. It is only in our days that the dreams of Ludwig von Bertalanffy and Norbert Wiener may come to fruition.

(Zeleny,1980: 120))

I have been drawn to this vision, but found that it has its limits (see Hofkirchner 2013 for recent development). My view of the limits of the cybernetic and general system-theoretical approach of architectonic and cosmogonial philosophies is that there seems to be no logical route, through any kind of empirically known and theoretically modeled emergence (Kim 2000, 2005), from an objective concept of information to a triadic pragmaticist semiotics. Not at least because it has the ethics, aesthetics and phenomenological philosophical basis that makes it compatible with human conscious and linguistic thinking processes (Brier 2008a, 2015b, Hofkirchner 2013).

One of the main deep problems in defining a universal information concept is, that all the ontological attempts to create objective concepts of information such as Claude Shannon's (Shannon 
and Weaver 1963/1948), Norbert Wiener's (Wiener 1963/1948) and John Archibald Wheeler's “it from bit" (Wheeler 1990, 1994, Wheeler and Ford 1998) results in concepts that cannot encompass meaning (Davies 2004) and experience of embodied living and social systems (Davies and Gregersen, 2009). When scientific methods are applied to information, cognition, and communication, we are only left with codes, grammar, phonetics, programs, formal language, copy machines, adaptors, but then the analysis of meaningful experience and relations is lost amidst all the formal technicalities. As Keeler (1995) writes:

From any (necessarily limited) human point of view, the meaning of any expression cannot be simply a matter of probability (established conventional response) or actuality (conditionally stimulated response) but must include possibility (an individual's unique experience in which the interpretation of meaning occurs) that cannot help but generate new meaning - growing experience. The essential continuity of experience, in which meaning is always a possibility in the future, is theoretically fundamental to Peirce's pragmatism (pragmaticism) - a point ignored by his contemporary, as well as by the modern, "pragmatists."

(Keeler 1995, p.9)

Wheeler's $(1990,1994,2004)$ "it from bit participatory universe" is one of the most influential cosmogonies presently, which furthermore has led to the info-computational view of the universe that sees humans, society and culture as well as all living nature as dominated by info-computational processes (Chaitin 2010, Dodig-Crnkovic and Müller 2011). Clara Moskowitz reports in Scientific American October 26, 2016 that hundreds of researchers in a collaborative project called "It from Qubit" are now saying that space and time may spring up from the quantum entanglement of tiny bits of information. Thus, Wheeler has had a great influence since his view in connecting classical and quantum mechanical ontology has been pitched through the peculiar idea of the delayed choice experiment. His core view is that every quantum event is a collapsing of the probability wave of specific existence to the manifestation of a thing that constructs a world:

...the universe is a 'self-excited circuit' - a system whose existence and whose history are determined by measurements. By 'measurement' I do not mean an observation carried out by a human or human-designed instrument - or by an extraterrestrial intelligence, or even by an ant or an amoeba. Life is not a necessary part of this equation. A measurement, in this context, is an irreversible act in which uncertainty collapses to certainty. It is the link between the quantum and classical worlds, the point where what might happen - multiple paths, interference patterns, spreading clouds of probability - is replaced by what does happen: some event in the classical world, whether the click of a counter, the activation of an optic nerve in someone's eye, or just the coalescence of a glob of matter triggered by a quantum event.

(Wheeler with Ford, 1998:

That is a pure quantum informational world without those aware subjects, the emergence of which Hankey is attempting to create the dynamic foundation fore. Chalmers is correct in seeing that the 
qualitative aspect of reality is totally missing in this theory, but can he fix it by just adding a phenomenological aspect to information theory that is not integrated in the basis of his philosophical framework from the start?

\section{The problem of explaining experience without a phenomenological basis}

The problem is in my view that Wheeler fails to establish a reflective phenomenological basis in human conscious cognition (Wheeler and Ford 1998:338). Such a basis is crucial in any attempt to explain the connection between natural sciences' foundation in human cognition, communication and culture and the model of the world it produces. Wheeler has his own precise view of "measurement":

..the essential feature of an act of 'measurement' is amplification from the quantum thing observed to the classical thing doing the observing, which need have nothing to do with human intervention or human consciousness.

(Wheeler with Ford, 1998.: 343).

I then do not understand what his use of the concept of 'observed' is indicating, unless he defines it as something machines and natural processes can do. That rules out the necessity of embodied consciousness then.

However, scientific knowledge has first-person embodied consciousness combined with secondpersons meaningful communication in language as a prerequisite for its third-person fallibilist knowledge. Therefore, a non-dualist study of consciousness forces us theoretically into a framework of unrestricted or absolute naturalism; viewing conscious quale life swith its intentionality as a part of nature. The crucial question is therefore: What is the role of consciousness, signs, and meaning in evolution as well as in cultural development? However, as we can see in Wheeler then the natural sciences are without concepts of qualia and meaning, and the European phenomenological-hermeneutic paradigm of qualitative sciences do not have an evolutionary foundation. Nevertheless, no matter how refined our empirical scientific approaches in neurophysiology and behaviour become, we cannot find any experiences in the brain. It does not matter if it is our own or other animals. The felt awareness seems to be found on another level of reality (Hinde, 1970) so far not discovered by the sciences. Something central about the brain's function, as an organ, escapes us (McGinn, 2000, Hofstadter, 2007, p. 373; Searle, 2007). Thus far, our only access to the first-person experiences is through meaningful verbal or written communication from the experiencing person (Heil, 2004, p. 3 ).

In contrast to these problems in Wheeler's philosophy of science framework and most European phenomenology and hermeneutics, Peirce consciously develops a phenomenology - called phaneroscopy in his triadic form -, which is foundational to his pragmaticist semiotics with its process and evolutionary cosmogony (Ransdell, 1989). Peirce writes:

Phaneroscopy is the description of the phaneron; and by the phaneron I mean the collective total of all that is in any way or in any sense present to the mind, quite regardless of whether it corresponds to any real thing or not. If you ask present when, and to whose mind, I reply that I leave these questions unanswered, never having entertained a doubt that those features of the phaneron that I have found in my mind are present at all times and to all minds. So far as I have developed this science of phaneroscopy, it is occupied with the formal elements of the phaneron. I know that there is another 
series of elements imperfectly represented by Hegel's Categories. But I have been unable to give any satisfactory account of them.

CP, 1.284)

Thus, his cosmogony is based on his phaneroscopy and his understanding of sign processes producing a naturalist integrated view of logic as semiotic that he developed after many years of research in the foundation of logic. I have explained a bit more about Peirce's philosophy in my other paper in the present issue of PBMB. However, here it is important to understand how Peircean semiotic pragmaticism differs from the mechanical as well as the info-computational cosmogonies. For many philosophers Peirce is primarily viewed as a logician. His integration of the traditional understanding of logic with a process semiotics based on three categories is unique in the history of philosophy and may therefore present some new solutions to our problems of placing our own conscious cognition and free will in the scheme of cosmogony and evolution. He wrote.

Logic will here be defined as formal semiotic. A definition of a sign will be given which no more refers to human thought than does the definition of a line as the place which a particle occupies, part by part, during a lapse of time. Namely, a sign is something, A, which brings something, B, its interpretant sign determined or created by it, into the same sort of correspondence with something, $\mathrm{C}$, its object, as that in which itself stands to $\mathrm{C}$. It is from this definition, together with a definition of "formal", that I deduce mathematically the principles of logic.

(Peirce 1980, 20-21; 54)

Peirce sees the world as a potential cognitive, creative process of reality proceeding through the interactive process between Firstness, Secondness and Thirdness that produces habits and signs in an irreversible time real evolution and a cosmogony or what he calls a hyperbolic cosmology:

I may mention that my chief avocation in the last ten years has been to develop my cosmology. This theory is that the evolution of the world is hyperbolic, that is, proceeds from one state of things in the infinite past, to a different state of things in the infinite future. The state of things in the infinite past is a chaotic emptiness, tohu bohu, the nothingness of which consists in the total absence of regularity. ... I believe the law of habit to be purely psychical. But then I suppose matter is merely mind deadened by the development of habit. While every physical process can be reversed without violation of the law of mechanics, the law of habit forbids such reversal.

(CP 8.317-318)

The real in Peirce's transdisciplinary pragmaticist paradigm is not only that which is external. The existent, or Secondness, is that, which reacts against other things and forces. The external world, then, does not consist merely of existent phenomena and their reactions because among the 'reals' Peirce also counts words, signs, general types and would-bes. Thus, Peirce is not a dualist, believing that the external world is completely independent of our semiosis or that there exists a "Ding an Sich" of which 
we can know nothing. He is a monist (CP, 6.24) - but not a physicalist or materialist one.

He calls his view objective idealism (CP 8.191), but his triadic semiotics makes it a rather unique realist and dynamical form. The unique in his philosophy is the view that the universe never completely escapes its sign nature and becomes a completely independent "thing" as is implicitly assumed in most natural science. He argues that for real knowledge and learning to occur, our only connection to the universe cannot be matter or - as I have argued modernizing his view - quantum "measurements". In Peirce's scholastic realism (Boler 1963), the Thirdness of reals are 'vagues', 'would-bes' or possibilities (CP 5.453). Thus, our ontology must include real tendencies and possibilities in the world (Thirdness) (Haack, 1992).

This is a view that the later Popper also endorsed in his theory of propensity (Miller 1975, Haack and Kolenda 1977). It is later exemplified in quantum physics, with its concept of virtual particles and probability waves that only have tendencies to exist in definite forms. That is an important aspect of Wheeler's cosmology (Wheeler 1994) and the theory of quantum foam. Thus, virtual particles only come into existence for a limited time; but they are predicted by the equations describing the laws of quantum physics and confirmed by experimental results. Peirce would call these phenomena natural habits. The singular particle, such as the electron, is a manifestation of the electron field or one could say, a token of the reals of its vacuum field. In addition, quantum mechanics points to the deep connection between observer and observed in the measurement process, but without any holistic theory of how the co-existence of the observer and the observed arises in cosmogony and how the consciousness of the human observer connects to the matter observed.

Peirce saw the development of a comprehensive metaphysical and epistemological system in which a new theory of categories - developed after Kant and Hegel - was defined in a completely new way (Esposito 1980) as his primary task: hence. His triadic category theory of Firstness, Secondness and Thirdness is connected to a dynamic triadic web of semiotics, where logic went far beyond the formal logic we know and became the study of the essential nature of signs. This is two important foundational moves away from the mechanical naturalism, where he differs from Wheeler and Chalmers and Hankey's use of them.

\section{Firstness and phenomenology}

Since Firstness in Peirce's philosophy is a state of absolute possibility of different qualities and radical indeterminacy as close to nothingness as possible, it is ontologically an absolute permissibility with no cause outside itself. It creates qualities from its own inner dynamics, just like the vacuum field in quantum field theory. From here, a specific Secondness emerges as one of multiple possibilities. An illustrative example could be one grain of sand from a whole desert, one specific particle in an ensemble, one specific phenomenological difference in quality. Thirdness is then the mediating, habit taking tendency of evolution between Firstness and Secondness. It contributes to the creation of an emergent order theoretically in a process with some similarities to Hegel's dialectical evolution and the dialectical materialism of Frederick Engels in his dialectics of Nature. In contrast to Engels, Peirce's categories also have a phenomenological aspect (CP 5.469) and produces a semiotic.

His semiotic logic is a central aspect of the pragmatic semiotics of cognition and communication of all living being, since Peirce's semiotics includes perception, signification and meaning construction, from the outset, as a basic aspect of reality alongside the physical, biological and social. In CP 5.488 
Peirce wrote that: all this universe is perfused with signs, if it is not composed exclusively of signs. Signs are thus, in his semiotic, not restricted to the living world alone in the sense that semiosis is also at work already in the pre-living development of the universe, or what Deely $(1997,2006)$ calls physio-semiosis: that is, signs develop within cosmogony, as part of the development of the universe's reasoning capability. Thirdness is the mediating, habit-taking aspect of evolution that contributes to the creation of an emergent order. Peirce wrote that:

Phenomenology, which does not depend on any other positive science, nevertheless must, if it is to be probably grounded, be made to depend upon the Conditional or Hypothetical science of Pure Mathematics, whose only aim is to discover not how things are but how they might be supposed to be ,if not on our universe, then in some other. A Phenomenology which does not reckon with pure mathematics, a science hardly come to years of discretion when Hegel wrote, will be the same pitiful club-footed affair that Hegel produced.

\section{(CP 5. 40)}

Evan Thompson (2007) defines phenomenology broadly as 'any systematic project of investigating and describing experience' (Thompson 2007, 474) and points to the deep connection that the continuity of life and mind has for Peirce's philosophy. It is Peirce's view that logic requires that any valid study of the complete cosmic process must be thus grounded in phenomenology, and not in any special science such as physics, as so many physicalist cosmogonies are today. For Peirce, phenomenology and mathematics are two foundations of his metaphysics because for him mathematics and logic are observational sciences, that is, they are based on experiment upon diagrams. (Haaparanta , 1994, CP 1.54) . Peirce wrote;

The first things I found out were that all mathematical reasoning is diagrammatic and that all necessary reasoning is mathematical reasoning, no matter how simple it may be. By diagrammatic reasoning, I mean reasoning which constructs a diagram according to a precept expressed in general terms, performs experiments upon this diagram, notes their results, assures itself that similar experiments performed upon any diagram constructed according to the same precept would have the same results, and expresses this in general terms. This was a discovery of no little importance, showing, as it does, that all knowledge without exception comes from observation.

(NEM 4, pp. 47-48) and

Thus for pierce, all valid necessary reasoning is, in fact, diagrammatic (Stjernfelt 2007, Peirce CP, 1.54). His phaneroscophy is a mathematization of phenomenology, searching for the original form in Firstness (Haaparanta ,1994). As Firstness for Peirce is pure feeling, then when integrating semiotics with cybernetics and systems theory as in cybersemiotics (Brier 2008a), the self-organizing power described by system theory is added to semiotics. When, furthermore, adding Maturana and Varela (1980 and 1986) and Luhmann's (1985) conception of autopoiesis, with its ability to explain how 
systems turn into individuals through closure, the job of explaining the qualitative emergence of mind

in communicating embodied nervous systems seems not far away. However, doing that job demands a system that does not commence with some fixed laws and a material concept of "a thing in itself" as the mechanical classical physical view of cosmology would have. Because not only is the concept of matter essential for the theory; so, too, are the concepts of time and law.

\section{Time-dependent laws as the habits of nature in a process agapistic philosophy}

Peirce describes the early phase of the becoming of the universe as almost timeless and if we rely on Einstein it would also be almost spaceless, because our world is created by unfolding space-time geometry. Thus, the world almost cannot be placed in time and space. Peirce wrote:

That first moment of time was of course infinitely long ago. But more than that, although it was but one moment, it was infinitely longer than any number of ages. It contained as great a multitude of ages as there are points upon a continuous line. In one sense this continuum was not time, it is true, because it all occupied but a moment of time. But it was not only strictly analogous to time, but it gradually and continuously developed into time; so that it was of one continuous nature with time. All that follows from the principles of continuity.

(NEM 4:139)

Interestingly, Wheeler (1994:300) - who had read some Peirce (Wheeler 1995:389, note 83) - is on the same track:

No laws. So far we can see today, the laws of physics cannot have existed from everlasting to everlasting. They must have come into being at the big bang. There were no gears and pinions, no Swiss watchmaker to put things together, not even a pre-existing plan ... Only a principle of organization which is no organization at all would seem to offer itself.

(Wheeler 1994:300)

Peirce differs from Wheeler by dint of a phenomenological and qualitative mathematical foundation which Peirce calls the tendency to take habits. He wrote about how the universe evolved from the time and space less void:

...there was already some tendency toward uniformity; and at any assignable date in the future there will be some slight aberrancy from law. Moreover, all things have a tendency to take habits. For atoms and their parts, molecules and groups of molecules, and in short every conceivable real object, there is a greater probability of acting as on a former like occasion than otherwise. This tendency itself constitutes a regularity, and is continually on the increase. In looking back into the past we are looking toward periods when it was a less and less decided tendency. But its own essential nature is to grow. It is a generalizing tendency; it causes actions 
in the future to follow some generalization of past actions; and this tendency is itself something capable of similar generalizations; and thus, it is self-generative. We have therefore only to suppose the smallest spoor of it in the past, and that germ would have been bound to develop into a mighty and over-ruling principle, until it supersedes itself by strengthening habits into absolute laws regulating the action of all things in every respect in the indefinite future.

According to this, three elements are active in the world: first, chance; second, law; and third, habit-taking.

$(C P, 1.409)$

When the triadic semiotic tendency to take habits or to assume regularity is fully manifested in cosmogony as one aspect of evolution, Peirce then calls it agapism, or the general principle of the action of love as a teleological process (W. 2.434). This is only one of the three types of evolution he conceptualized, of which only one includes Darwinian evolution - namely the tychastic form or free sporting, where selection is based on random mutations. In the paper from 1893 in The Monist called 'Evolutionary love', Peirce describes his triadic view of evolution this way:

Evolution by sporting and evolution by mechanical necessity are conceptions warring against one another. A third method, which supersedes their strife, lies enwrapped in the theory of Lamarck. According to his view, all that distinguishes the highest organic forms from the most rudimentary has been brought about by little hypertrophies or atrophies which have affected individuals early in their lives, and have been transmitted to their offspring. Such a transmission of acquired characters is of the general nature of habit-taking, and this is the representative and derivative within the physiological domain of the law of mind.... Lamarckian evolution is thus evolution by the force of habit. ... Now it is energetic projaculation ... by which in the typical instances of Lamarckian evolution the new elements of form are first created. Habit, however, forces them to take practical shapes, compatible with the structures they affect, and, in the form of heredity and otherwise, gradually replaces the spontaneous energy that sustains them.... this account of Lamarckian evolution coincides with the general description of the action of love.... Remembering that all matter is really mind, remembering, too, the continuity of mind, ... Three modes of evolution have thus been brought before us: evolution by fortuitous variation, evolution by mechanical necessity, and evolution by creative love,... tychism, anancism, and agapism.

$(C P, 6.299-302)$

Agapism is described by Peirce as a very general force of creative love that work in cosmogony, which expresses itself in a devotion to cherishing and tending to aspects of reality other than oneself. He wrote:

The agapastic development of thought should, if it exists, be distinguished by its purposive character, this purpose being the development of an idea. We should have a direct agapic or sympathetic 
comprehension and recognition of it by virtue of the continuity of thought. I here take it for granted that such continuity of thought has been sufficiently proved by the arguments used in my paper on the "Law of Mind" in The Monist of last July.

(CP 6.316)

As Peirce sees matter as being to a certain degree alive inside - like Aristotle - it is not so difficult to understand why development and evolution in his Schelling-inspired cosmogony is viewed not as a machine algorithm, but as a sort living reasoning process:

What is reality? Perhaps there isn't any such thing at all. As I have repeatedly insisted, it is but a retroduction, a working hypothesis which we try, our one desperate forlorn hope of knowing anything. Again it may be, and it would seem very bold to hope for anything, that the hypothesis of reality though it answers pretty well, does not perfectly correspond to what is. But if there is any reality, then, so far as there is any reality, what that reality consists in is this: that there is in the being of things something which corresponds to the process of reasoning, that the world lives, and moves, and HAS ITS BEING, in a logic of events. We all think of nature as syllogizing.

(Peirce 1992: 161)

What is the consequence of adopting a cosmogonical theory of the development of nature or the whole universe as syllogizing? It shifts one's cosmology from the statistically-based meaning-less concept of information to a semiologic cosmology, thereby through the phenomenological foundation introducing a natural concept of meaning.

\section{Meaning goes beyond probability}

To think of all of nature in terms of syllogizing is to advance beyond a statistical probabilistic view, as, for instance, Prigogine's order out of chaos does through non-equilibrium thermodynamics (Prigogine and Stengers, 1984). Probability - statistical, based on a fix set of outcomes - is not possibility. As Peirce wrote: ".. to assert that any source of information that is restricted to actual facts could afford us a necessary knowledge, that is, knowledge relating to a whole general range of possibility, would be a flat contradiction in terms."(CP 4.232).

The point is that the meaning of any expression exceeds probability! This is because an individual's unique experience -from which the interpretation of meaning occurs - cannot avoid generating new meaning, since meaning is always connected to future possibility of action. This is what Niklas Luhmann understands through his concept of 'horizons of meaning' (Luhmann 1995 and $1996 \mathrm{a}+\mathrm{b})$. Meaning amounts to the possible types of action a message can produce in the future. This theoretical understanding is fundamental to Peirce's pragmaticism (Keeler 1995). Thus, Peirce attempted to broaden the view of logic, entailing that formal logic is only one aspect of logic ,showing that logic is semiotic:-: "Logic, for me, is the study of the essential conditions to which signs must conform in order to function as such" (Peirce MS 291). This is pretty much Peirce's formulation of the 
principle of the self-organization of the universe that systems and cybernetics has developed (Jantsch 1980). It is the view that that comprehensible reality is alive:

The business of philosophy is to explain the relation between being and appearing; ... The reality is that on which the appearances is founded and, therefore the "being" of a thing is its creator, while the "existence" is the creature in himself... But if an underlying being is essential to existence, no less is manifestation essential to being. It can make no difference whatever a thing is or is not, if it is never to any mind to give any sign of its being. Hens to be without being manifested is a kind of being which does not differ from its negative, but is a meaningless form of words. Thus, it is of the very essence of being that it shall come forth into appearance, ... To give being is to give life, or being is life. (W 2.434)

As such, Peirce sees signs as possessing a sort of life of their own in being dynamic creatures of logical development. Peirce's logic-as-semiotics is a cosmogonial theory of the creative reasoning of the universe as a developmental and evolutionary process. Peirce's ontology has a semiotic layer consisting of the reality of growing symbolic semiologic intermingling with matter and energy.. Here is a quote that makes it clear how Peirce sees logic-as-semiotic processes permeating all levels of living systems:

The cognition of a rule is not necessarily conscious, but is of the nature of a habit, acquired or congenital. The cognition of a case is of the general nature of a sensation; that is to say, it is something which comes up into present consciousness. The cognition of a result is of the nature of a decision to act in a particular way on a given occasion. In point of fact, a syllogism in Barbara virtually takes place when we irritate the foot of a decapitated frog. The connection between the afferent and efferent nerve, whatever it may be, constitutes a nervous habit, a rule of action, which is the physiological analogue of the major premise. The disturbance of the ganglionic equilibrium, owing to the irritation, is the physiological form of that which, psychologically considered, is a sensation; and, logically considered, is the occurrence of a case. The explosion through the efferent nerve is the physiological form of that which psychologically is a volition, and logically the inference of a result. When we pass from the lowest to the highest forms of innervation, the physiological equivalents escape our observation; but, psychologically, we still have, first, habit-which in its highest form is understanding, and which corresponds to the major premise of Barbara; we have, second, feeling, or present consciousness, corresponding to the minor premise of Barbara; and we have, third, volition, corresponding to the conclusion of the same mode of syllogism.

(CP 2.711) .

This process view is close to Hegel's spiritual and Marx's material dialectics, but the Peircean processes work in a semiotic ontology attempting to encompass both mind and matter as two different complementary aspects of a non-dual ontology. Peirce's emptiness ontology allows his reality to manifest not from spirit, nor from matter, but from the void or pure Zero, as he calls it. See also my other paper in this issue: How Peircean biosemiotics connects scientific Western science with Eastern Emptiness Ontology). The important distinction from related perspectives is that Peirce sees all 
thinking developing through signs in culture and nature as well, with symbols as the most important, which we will deal with in the next section.

\section{Thought is not necessary connected with a brain}

This headline is one of Peirce's most revolutionary expressions, particularly when taking into account that it comes from an educated chemist that has been working in physical empirical science. The full quote explains more:

Thought is not necessarily connected with a brain. It appears in the work of bees, of crystals, and throughout the purely physical world; and one can no more deny that it is really there, than that the colors, the shapes, etc., of objects are really there. Consistently adhere to that unwarrantable denial, and you will be driven to some form of idealistic nominalism akin to Fichte's. Not only is thought in the organic world, but it develops there. But as there cannot be a General without Instances embodying it, so there cannot be thought without Signs. We must here give "Sign" a very wide sense, no doubt, but not too wide a sense to come within our definition.

Peirce sums up his view on logic, the reasoning capacity in the universe and the integration of chance, love and logic in a way that is very close to Aristotle's Nus and episteme, yet embedded in a process view.Peirce tries to solve our problem of finding our place in the universe and how we are connected to nature. Inspired by Buddhism and transcendental Christianity, Peirce suggests that the universe is the immanent part of the divine and that the other "part" from which it emerges is a transcendental emptiness (Tohu Bohu) "behind and before" the manifest world. This cosmogony has similarities to Wheeler's: no space and no time (1994: 311). Wheeler (1994), Smolin (2014) and Peirce agree on the fundamental process view that natural laws do not exist before the development of the universe, but develops as new layers of being emerge. This view of natural laws in cosmogony is contrary to Stephen Hawking's mechanical deterministic universe, where the cosmogony is based on fixed transcendental universal laws. Peirce holds on to a realistic view, without the limitation of Kant's philosophy of "Das Ding an Sich", because he empirically grounds his process semiotics in truth and logical relations. But if we must cease to see the universe as a machine, what metaphor would then be suitable for a process philosophy? For Peirce it is what he calls a symbol, a concept more fundamental than language.

\section{The universe as a symbol developing reasoning}

In Kania Stoicheia (EP2:322-24) Peirce argues for the understanding of the nature of the newly born universe as that of a vagues and almost empty symbol in order to provide an agapastic understanding of how the universe emerges and develops in an understandable way. For Peirce, this isa key factor for how to make the world an intelligible and a more reasonable place than the material mechanical ontology of classical science can produce. This is an aspect of Peirce's attempt to solve the 
riddle of how we human's are so good a guessing the right causal models of how nature works. Peirce's thought-provoking statement is as follows:

nothing, the indeterminate of the absolute beginning, is a symbol. That is the way in which the beginning of things can alone be understood. ... Now it is of the essential nature of a symbol that it determines an interpretant, which is itself a symbol. A symbol, therefore, produces an endless series of interpretants.

(EP vol. 2 322-23)

This quote on the self-organizing capability of the universe is the core of Peirce's cosmogony and epistemology and carries the idea that all the laws of nature are semiotic habits arising from a cosmological development of reasoning. This is similar to the self-orgnization concept in system science and cybernetics. However, in Peirce's theory it is the triadic sign producing process's irreversibility that creates the flow of time, which is causing general evolution plus the development of complexity as the continuous flow of causation.

The development of modern physics since Peirce's death - as noted above- lends a new scientific exemplification of his generalized concept of habits that also supports biosemiotics' view of causality and evolution. The development in the ontology of modern science seems to have supported some of Peirce's metaphysical views. Among them are the development of non-linear systems, complex systems theory, non-equilibrium thermodynamics, and quantum theory. These all develop the ontological framework of the natural sciences toward views that seem to support Peirce's general architectonic framework. Specific examples, here, include the irreversibility concept of time in nonequilibrium thermodynamics of Prigogine, which supports Pierce's critique of the reversible time concept in mechanistic ontology. Furthermore chaos theory in non-linear and complexity systems (Abraham 2011) where chance is viewed as objective, seemingly supports Peirce's Tychism. Peirce's theory of 'flashes' in his early cosmogony cseems similat to the modern concept of symmetry breaking (Arodz, Dziarmaga and Zurek 2003) Peirce wrote:

Our conceptions of the first stages of the development, before time yet existed, must be as vague and figurative as the expressions of the first chapter of Genesis. Out of the womb of indeterminacy we must say that there would have come something, by the principle of Firstness, which we may call a flash. Then by the principle of habit there would have been a second flash. Though time would not yet have been, this second flash was in some sense after the first, because resulting from it. Then there would have come other successions ever more and more closely connected, the habits and the tendency to take them ever strengthening themselves, until the events would have been bound together into something like a continuous flow.

(CP 1.12)

In the development from vagueness as possibility of forms it is important to understand the nature of the symbolic sign in Peirce's semiotics, signs are viewed as possible types, which then manifest in tokens in real time and space. The distinction between a type and its tokens or its replicas is an ontological one in semiotic process philosophy. The type is understood as a general sort of 
phenomenon and the token or replica as its particular concrete instances. This is very useful for the understanding of quantum phenomena. They can be viewed as would-be dynamical forms that manifest as tokens in particles when clashing with the measurement apparatus - for example, the photographic emulsion in the double slit experiment -and making a black dot in a photo emulsion. Peirce clarifies:

A sign is something that exists in replicas. Whether the sign "it is raining" or "all pairs of particles of matter have component accelerations toward one another inversely proportional to the square of the distance" happens to have a replica in writing, in oral speech, or in silent thought, is a distinction of the very minutest interest to logic, which is a study, not of replicas, but of signs.

(NEM 4, 248)

This is where I find Peirce to have developed Aristotle in that he incorporates a complex understanding of evolution into his hylopathic view of the basic stuff of the cosmos and rendering Aristotle's formulations part of a true semiotic process philosophy. Distinctively, Peirce operates with emptiness, or a pure Zero, as the origin of the world. This is not to define the origin negatively as a lack of content, but positively as a potentiality in the form of a Superorder of tychastic free chance operation dynamics. Thus, the world we now live in - Peirce argues - is only one possibility of an eternal number of other worlds. This view is clearly consonant with the present theory of multiverses in physics (Carr 2007, Davies 2007)). For Peirce,

Pragmaticism, then, is a theory of logical analysis, or true definition; and its merits are greatest in its application to the highest metaphysical conceptions. ... A disembodied spirit, or pure mind, has its being out of time, since all that it is destined to think is fully in its being at any and every previous time. But in endless time it is destined to think all that it is capable of thinking. Order is simply thought embodied in arrangement; and thought embodied in any other way appears objectively as a character that is a generalization of order, and that, in the lack of any word for it, we may call for the nonce, "Super-order." It is something like uniformity. The idea may be caught if it is described as that of which order and uniformity are particular varieties. Pure mind, as creative of thought, must, so far as it is manifested in time, appear as having a character related to the habit-taking capacity, just as superorder is related to uniformity. ... perfect cosmology must therefore show that the whole history of the three universes, as it has been and is to be, would follow from a premiss which would not suppose them to exist at all. Moreover,.... Consequently, whether in time or not, the three universes must actually be absolutely necessary results of a state of utter nothingness.

$(\mathrm{CP}, 6.490)$

So, Peirce's answer is that because we inhabit just one of many possible universes, we should not forget that even in the creation of such a stable universe, which may be the only one available to us, there is a necessary process in this of trying to create all possible universes. Thus when we ask, "Why this world with these physical constants?" as Wheeler (1994) and Davies (2007) do, then the answer could align with the anthropic principle (Davies 2007): that it is because we are here as observers that this universe is as it is and that is only possible with these constants and these habits. We can theorize 
about the necessity of assuming other universes (Carr 2007, Unger and Smolin2014), but empirically we do not know if there are other universes because they have not established such a basic semiotic relation between observers and universe as ours has. The other possibility is that they have, but they are closed around their own existence like physicists says our universe is. We cannot get into contact with those other universes because we simply do not possess a means of access to them. In contrast to Wheeler's 'it from bit' interactive universe that lacks an ontology of living systems conscious observation - a concept so crucial to his theory of the participatory universe (Wheeler 1992: 293) - the observer is viewed by Peirce as a symbol in an ongoing growth process of knowing; in a universe that is growing to a grand argument (another form of symbol). As Peirce points:

Therefore, if you ask me what part Qualities can play in the economy of the universe, I shall reply that the universe is a vast representamen, a great symbol of God's purpose, working out its conclusions in living realities. Now every symbol must have, organically attached to it, its Indices of Reactions and its Icons of Qualities; and such part as these reactions and these qualities play in an argument that, they of course, play in the universe -- that Universe being precisely an argument.

(CP 5.119)

These tokens may be things and they may be signs or both. This view seems to be a modern formulation of the idea of 'creative intelligence' found in Adi Shankara's Advaita Vedanta's non-dualism (Brier 2009). It has the advantage of theoretically connecting and integrating our self and the origin of the universe:

The philosophy of advaita, literally non-dualism, is the premier and oldest extant among the vedanta schools of Indian philosophy. The upanishadic quest is to understand brahman, the source of everything, the Atman, the Self, and the relationship between brahman and Atman. ... The advaita school teaches a complete essential identity between brahman and Atman. In other vedantic traditions, the essential relationship between Atman and brahman is understood in different ways.

(“Advaita Vedanta Home Page” http://www.advaita-vedanta.org/avhp/ 5. Jan09)

What is special about the Advaita Vedanta tradition in contrast to Western views of science, religion and human nature, is that it claims, just like the major forms of Buddhism, not to be a religion in our ordinary theistic way.

In the West, there remains interest in understanding and using this paradigm (see, for instance, Rock 2005). Rather than claiming the status of a religion per se, the Indian Advaita Vedanta considers itself a foundation for all religions. Vivekananda is famous for presenting India and Hinduism at the Parliament of the World's Religions in 1893 (Brier 2009). That includes not only those that we now know under the Western concept of "Hinduism", but all world religions. This Advaita Vedanta corresponds with that of Emerson and the Concord Transcendentalists (Emerson 1883) view of the connection between human mind and nature. 
Vedic texts assert that the Absolute Truth exists as an unmanifest possibility. This unmanifest creates the manifest in itself. You cannot, in the normal semiotic way, experience the unmanifest in itself. Like Firstness you can only know it through analyzing the manifest reality created from the possible. We only know the present when it is already a past. Peirce's logic of events regards the present state of the universe as having evolved from an original state of things in which there was "no compulsion and no law" (CP 6.217). Thus the rationale of evolution is not limited to deductive logic, the only kind of inference that can be exact, but is rather an abduction to the adjacent possible (Kauffman 2012). This is the inferential approach to evolution and ecology, which have been explicated by Stjernfelt (2014). Peirce puts the matter in the following way:

It is true that the whole universe and every feature of it must be regarded as rational, that is as brought about by the logic of events. But it does not follow that it is constrained to be as it is by the logic of events; for the logic of evolution and of life need not be supposed to be of that wooden kind that absolutely constrains a given conclusion. The logic may be that of the inductive or hypothetic inference. (CP 6.218)

Peirce's theory incorporates a phenomenological and mathematical foundation for cosmogony and, as a further aspect of Peirce's pragmaticist philosophy, integrates the three normative sciences of aesthetics, ethics and logic in an ongoing process. As such one can characterize Peirce's view from Davies (2007) as a combination of his: C. multiverse explanation, E. The life principle theory " ...it builds purpose into the workings of the cosmos at a fundamental (rather than an incidental) level, without positing an unexplained preexisting agent to inject purpose miraculously" (Davies 2007: 266) and F. The selfexplaining universe which " ... appeal to a closed explanatory or causal loop. In effect the...multiverse...explains itself...Perhaps all self-explanatory schemes exist and only ones like ours get observed because they are consistent with life... I have suggested that only self-consistent loops capable of understanding themselves can create themselves, so that only universes with (at least the potential for) life and mind really exists." (Davies 2007:267). I see this last suggestion of Davies as a fruitful development of Peirce's cosmogony since the multiverse theory was not known in his timebut now has become widely accepted.

What fascinates me about this interpretation is its general process ontology, which is compatible with science. Furthermore it integrates the "normative" sciences andphenomenology and thus allowing for the qualitative sciences by way of a non-reductive encapsulation of all the sciences as a non-reductive alternative to logical positivisms and physicalistic as well as info-computational views of unity science (Brier 2008). It is also interesting that Peirce's perspective prefigures a combination of modern quantum field physics, non-equilibrium thermodynamics and system theory, including selforganization theory. Peirce finishes his Monist paper On the Law of mind in this way:

I have thus developed as well as I could in a little space the synechistic philosophy, as applied to mind. I think that I have succeeded in making it clear that this doctrine gives room for explanations of many facts which without it are absolutely and hopelessly inexplicable; and further that it carries along with it the following doctrines: first, a logical realism of the most pronounced type; second, objective idealism; third, tychism, with its consequent thoroughgoing evolutionism. We also notice that the doctrine presents no hindrances to spiritual influences, such as some philosophies are felt to do. 
(CP, 6.163)

In Peirce's concept of causality the dynamics of the symbol plays a crucial role. The conclusion is that to be able to act coherently, the teleology of living beings must be an expression of true semiosis, which is able to transmit forms from causes into effects. This is possible because symbols are the living signs capable of gathering information during perception and conveying it to its interpretants producing general habits of conduct. Peirce, in fact, was ahead of both Prigogine's non-equilibrium thermodynamics) and quantum theory because the metaphysics he developed is able to encompass them all in a worldview that integrates all these new understandings. We need, also, to come to terms with Peirce's ontology and its semiotic epistemology in the development of the philosophical foundation of biosemiotics. We need this new non-reductionist and expanded naturalism, where, as Peirce writes:

... a way of thinking; and the possibility of science depends upon the fact that human thought necessarily partakes of whatever character is diffused through the whole universe, and that its natural modes have some tendency to be the modes of action of the universe.

(CP 1.351)

Peirce's conception entails that instinctive, perceptual and adductive cognition is connected through the law of mind or the tendency to take habits in relation to behavior in animals or human Umwelten. For Peirce, the non-mechanistic understanding of nature and all living systems as self-organizing habits connect the tendency to take habits in cosmogony with the development of perceptions and instinct in animals, as well as the ability to do abductive problem-solving reasoning in higher animals and man. This connection leads to an answer to the problem of a fallibilist philosophy of science, recognizing the basis in abduction of scientific creative thinking and the impossibility that the proof of hypothesis is solely to be found in causality of patterns thrown up by empirical work. How is it that we are so good at guessing laws and models that fit nature so well when there is no deductive logic leading from perception to theory? Peirce's answer is that it is because our inferential abilities, through the habit taking of evolution, are products of the same nature we investigate. This deep connection between our "inner" way of making sense of our perceptions and our ability to see regularities and causes in "outer" nature is the explanation of what Galilei called Il lume natural. It is the inner light that allows us to see nature's workings. Hans Moravec (1988) writes in a similar vein:

Encoded in the large, highly evolved sensory and motor portions of the human brain is a billion years of experience about the nature of the world and how to survive in it. The deliberate process we call reasoning is, I believe, the thinnest veneer of human thought, effective only because it is supported by this much older and much more powerful, though usually unconscious, sensorimotor knowledge.

(Moravec 1988:15-16).

Peirce views the life of signs as a self-organizing and developing process. Like a virus, signs selforganize and reproduce through their tokens, without signs being themselves fully embodied living creatures. Yet, signs are embodied by us through our thinking and imagining.. Symbols grow by nature 
and are supported by the tendency to take habits, be this in human biology, mind or culture. This explains Peirce's view of how the tendency to take habits, and symbolic dynamics, are the driving forces across the realms of physics, chemistry, biology, psychology and sociology! His is a true transdisciplinary view; or as Romanini (2014: 239) writes:

But the description of living process is not all that biology is about. It is also about understanding how life itself is possible and how biological processes can produce evolution, consciousness, meaning, representation and communication. Biosemiotics is a branch of biology interested in understanding life as semiosis, where meaning and interpretation plays the central role. Applying Peirce's theory of signs to biosemiotics will certainly help the development of biosemiotics, but it might equally help the development of Peirce's proposal for a logical theory of reality. His admonishment for a logically grounded metaphysics to deal with the vital questions of life must be taken into consideration by biosemioticians. ... The scientific question about the biological meaning of life and the metaphysical question about the logical meaning of life might have, at the end, the very same answer.

If science is a way of knowing the universe and how it works, then religion is a way of making sense of our relationship with the universe and all the other forms of living intelligence in it. If these are two sides of the same coin, then the coin is us, not the universe itself, and it raises the problem of whom or what we are. If we want to have a non-reductionist unity of science that will include the quantitative and the qualitative sciences as suggested by cybersemiotics (Brier 2008a) then we will have to develop our ontological and epistemological view of humans and the possible function of our knowing process in the universe. An aspect of our body can be described by science in an evolutionary and ecological framework; but are we related to the universe in other ways than science can thus far describe?

Gregersen (2003) has, from the background of a Whiteheadian process philosophy, worked on the problems for decades with several partners in a conceptualization that in many ways dovetails with the Peircean view presented here.

Peirce makes mathematics and consciousness converge through his three-category-based semiotics, where logic is semiotic. We know that reality is not a deterministic algorithm playing itself out because QM experiments are tied to the free will choice of a measurement, as Wheeler (1994) points out. The concept of codes and signs has this choice element, since a code must be operated by a system encompassing free will to make choices. A language is simply a finite set of symbols with rules and freedom. The freedom in the codes of language is what ensures they are not deterministic algorithms and can continuously create new expressions. However, it is not possible to operate the free part of a code randomly or it will break down; there must be something else. That something is relation, which is impossible to establish between a res externa and res cogitans in a Cartesian dualism and a Kantian transcendentalism where things in the outer world become "things in themselves" that cannot be known. The result of this is that the philosophical possibility of scientific knowledge breaks down. A non-dualist philosophical framework seems necessary to solve the conflict.

Peirce's semiotics avoided the pitfalls of a dualist philosophical framework by means of a synechistic monism, where mind and matter are different ends of a continuum. Matter is effete mind inveterate habits becoming physical laws (CP, 6.25). Since Firstness is a state of absolute possibility and radical indeterminacy as close to nothingness as possible, it is an absolute permissibility with no cause outside itself. From here, Secondness emerges as one of many possibilities as difference, otherness, individuality, limit, force and will. Thirdness is the mediating, habit-taking aspect of evolution that contributes to the creation of an emergent order. This synechism is also the basis for Peirce's fallibilism and his objection to the idea of transcendental absolute mechanical laws governing 
the cosmogony. We do not have absolute knowledge. The laws are rather vague tendencies in the beginning that become more and more rigid habits as the universe unfolds. Nature may not be mathematical in itself but we have created mathematical models that fit much of our empirical data.

As all matter-energy needs to be moving for us to observe it, then there must be something from where it is moved, which is not matter (Deely and Ashley 2012). For Peirce, it is emptiness or nothingness, pure zero. According to this unbroken field view, there has to be some deep invisible connection between matter and mind. Peirce integrates chance as a foundational element by establishing a spontaneous foundation, as in Quantum field theory, which he calls tychism. It is a level of pure potentialities, like the modern theoretical idea of the quantum vacuum field that is never at rest. But since this mind-matter continuum through synechism does not allow matter to be dead and mechanical, he also considers the spontaneously generating field as a force of possible existence of quale-consciousness.

Hartshorne and Reese (1853) call Peirce's view Panentheism, corresponding with Chalmers' (2010) idea of force outside the physical universe. In this view the divine is both transcendental "before", "outside" and "under" the material space-time reality; but it is also immanent, meaning "inside" as a driving force of evolution, a sort of creative intelligence or Agapism. This divine foundation is also our foundation and there is no absolute limit to our knowledge about it. This is what is central in Peirce's break with Kant's idea of a "Ding an Sich". The break occurs because, on the one side, Peirce does not ascribe to a religious worshipping of a personal god completely apart from all human beings; and, on the other, he does not ascribe reality to a dead mechanical material reality as mainstream natural science does today. Peirce's triadic synechistic process philosophy provides a solution to the deep problems in materialist and dualist metaphysics. It is fairer to call it a non-dualism like Shankara's Advaita philosophy. For Shankara, Brahman is the one and only reality. Brahman is Being, Consciousness, and Bliss. In this panentheist philosophy Brahman, which is the ultimate reality, is non-dual. This means that that Brahman and Atman are a unity, that the appearance of plurality in the phenomenal world is therefore illusory. This illusion is called maya and is the reason for the misinterpretation of multiple appearances as reality, when Brahman is really infinite, formless, and the eternal and unchanging Self. Thus, through his combination of the transcendentalists' insight and German idealism's evolutionary perspective in his triadic semiotic process philosophy, combined with a fallibilist empiricist attitude, Peirce is able to absorb most of the development of modern science and solve Neo-Darwinism's problem of explaining how mind emerges in evolution. Consider the following:

The endless variety in the world has not been created by law. It is not of the nature of uniformity to originate variation, nor of law to beget circumstance. When we gaze upon the multifariousness of nature we are looking straight into the face of a living spontaneity.

(CP 6.553).

Love, in Peirce's conception, is related to the recognition and understanding of the law. The importance of love in agapism's dynamic process view of the divine is to fuel the evolutionary growth of reasoning and the concept is therefore essential for Peirce's theory of science. Peirce shows that an ontology of the world as a closed and dead mechanism, deterministically run by universal laws, is inadequate as a framework for a theory of meaningful knowledge and empirical quantitative science. Thus, in Peirce's understanding, creation is open-ended. Furthermore, for Peirce, man's self is a developing symbol in the huge argument of the universe. The sciences can then be considered as systems of rationalized 
expectations in social commitment. These rationalized expectations are carried by collectives and their scholarly discourses, which is a special kind of communication system . What Luhmann (1995) calls generalized symbolic media of which science is one - that leads to a collective, impersonal, still fallible knowledge. Logic to Peirce is thus the intersubjective product of a social, ethical striving for common rationality and the Summum Bonum, which is how he ideally viewed science. The Peirce scholar Kelly Parker (Parker 1998) nicely sums up Peirce's evolutionary view:

As law takes hold, the evolving cosmos can be seen wending its way toward a Universe of Necessity, in which law would be perfect. This Universe is the completely reasonable state of things that is identified (in Peirce's aesthetics) as an ideal. This universe is on the one hand unrealizable in principle, since it would imply the complete eclipse of Possibility and Haecceity, which are as fundamental as Necessity; on the other hand, it is the regulative ideal toward which self-controlled thought and action aim. The increase of reasonable thought and action, in the context of all three universes, is accordingly the summum bonum in Peirce's philosophy. ... it is notable that Peirce, like Plotinus, sees the origin of the universe as the result of a spontaneous (i.e. uncaused) act of creation. This act of creation proceeds through stages, and both philosophers see the realm of existent bodies as an imperfect reflection of the realm of Forms that is the proper object of knowledge. Though the pregnant Nothing of the zero-state bears some affinities to the Plotinian One, there is apparently no room in Plotinus for Peirce's doctrine of tychism, his insistence on irrational chance as the driving force behind creation. The Plotinian One is the ground of creativity and necessity. Peirce separates these two principles. Creativity is Firstness, the generative principle, while necessity is Thirdness, the end toward which events in the universe are drawn.

(Parker http://agora.phi.gvsu.edu/kap/Neoplatonism/csp-plot.html

Peirce's guiding principle in respect of how religion and science is deeply connected differs from what any other philosopher has suggested, apart, perhaps, from Whitehead's well-crafted process philosophy (Schilpp 1941).

Hankey (2015:299) clearly sees, like Peirce, that generalizations -Thirdness in Peirce - are created through the fact that the "brain naturally connects cognition through associated memories to the next course of action." This pragmaticist view is very close to Peirce's and brings us back to the normative behavior of conscious embodied interactions in self-organized meaning through signs. Peirce's nondual semiotic triadic process semiotics could do wonderful things for Hankey's theory by replacing Chalmers', Bateson's and Wheeler's theory of mind.

\section{Acknowledgements}

I thank Paul Cobley for dialogue on the semiotic and communicative aspects of the paper and for improving my English expression. To Alex Hankey for discussion in Tucson and productive critique of an earlier version of the paper, bringing my attention to his new and synthetic work and to the anonymous referees for constructive critique.

\section{References}

Abraham, R. (2011). The Genesis of Complexity, World Futures: The Journal of New Paradigm Research, Volume 67, Issue 4-5, 2011 pages 380-394 
Arodz, H., Dziarmaga, J. and Zurek. W. H. (2003). Patterns of Symmetry Breaking, Bind 127 af NATO science series: Mathematics, physics, and chemistry, Netherlands: Springer

Bars, B. (1997). In the Theatre of Consciousness: the Workspace of the Mind, Oxford: Oxford University Press.

Bateson, G. (1973). Steps to an Ecology of Mind: collected essays in anthropology, psychiatry, evolution and epistemology. St. Albans: Paladin.

Bennet, M. and Hacker P. (2007). The Philosophical Foundation of Neuroscience. In Bennet, M., Dennet, D., Hacker, P. and Searle, J. (2007). Neuroscience \& Philosophy: Brain, Mind \& Language, New York: Columbia University Press.

Bhaskar, R.A., (1975), A Realist Theory of Science, London: Verso.

Bhaskar, R.A., (1979), The Possibility of Naturalism. London: Routledge

Bhaskar, R.A. (1999). Dialectic: The Pulse of freedom, London: Verso.

Bhaskar, R.A. (2000). From East to west: Odyssey of a soul. London: Routledge.

Bhaskar, R.A., (2002a). Reflections On Meta-Reality: A Philosophy for the Present, New Delhi/London: Sage.

Bhaskar, R.A. (2002b). From science to emancipation: Alienation and the actuality of enlightenment. London: SAGE.

Bhaskar, R.A. (2002c). Meta-reality/ 1, Creativity, love and freedom. New Delhi : Sage Publications.

Bhaskar, R.A. (2002d). Reflections on meta-reality: transcendence, enlightenment, and everyday life. Thousand Oaks, Calif. : Sage Publications.

Bhaskar, R.A. (2002e). Beyond east and west: spirituality and comparative religion in an age of global crisis. New Delhi ; Thousand Oaks, CA : Sage Publications

Bishop, Donald. H. (1981). "Peirce and Eastern thought" in K. L. Ketner et al. (Eds.), Proceedings of the C. S. Peirce Bicentennial International Conference, pp. 265-270, (Lubbock: Texas Tech Press).

Boler, J. F. (1963). Charles Peirce and Scholastic Realism, Seattle: University of Washington Press.

Brier, S. (1992): "Information and Consciousness: A Critique of the Mechanistic foundation of the Concept of Information" in Cybernetics \& Human Knowing, Aalborg, Denmark, Vol.1, no. 2/3, pp 7194. 
Brier, S. (1999). "Biosemiotics and the foundation of cybersemiotics. Reconceptualizing the insights of Ethology, second order cybernetics and Peirce's semiotics in biosemiotics to create a non-Cartesian information science", Semiotica, 127-1/4, 1999, 169-198.

Brier, S. (2008). “A Peircean panentheist scientific mysticism”, International Journal of Transpersonal Studies 27: 20-45.

Brier, S. (2011):'Ethology and the Sebeokian way from Zoosemiotics to Cyber(bio)semiotics", Deely, John, Kull, Kalevi and Petrilli, Susan (eds.): Semiotics Continues to Astonish: the Intellectual Heritage of Thomas Albert Sebeok, Chapter 4, pp.: 41-84, Paris and Den Haag: Mouton de Gruyter.

Brier, S. (2014). Pure Zero, in Thellefsen, T. and Sørensen, B.(2014): Charles Sanders Peirce in His Own Words: 100 Years of Semiotics, Series: Semiotics, Communication and Cognition [SCC] 14. Berlin, New York: De Gruyter Mouton, pp. 207-12.

Brier, Søren (2015a). Can Biosemiotics be a "Science" if its Purpose is to be a Bridge between the Natural, Social and Human Sciences? In: Progress in Biophysics \& Molecular Biology, Vol. 119, No. 3, 2015, p. 576-587.

Brier, S. (2015b). Finding an Information Concept Suited for a Universal Theory of Information. Progress in Biophysics \& Molecular Biology, 119(3), 622-633.

Brier, S. (2015c). Cybersemiotics and the reasoning powers of the universe: philosophy of information in a semiotic-systemic transdisciplinary approach, Green Letters, Studies in Ecocriticism. Volume 19, Issue 3, 2015,Pp: 280-292:

Brier, S. (2017). How to Produce a Transdisciplinary Information Concept for a Universal Theory of Information?, Chapter 2 in: Burgin, M. and Hofkirchner, W. (2017). Information Studies and the Quest for Transdisciplinarity: Unity through Diversity, World Scientific Series in Information Studies: Volume 9, Singapore: World Scientific.

Carr, B. (Ed.).Universe or Multiverse? (2007Cambridge: Cambridge University press.

Chaitin G. (2010). Mathematics as a Biological Process. In Dodig-Cmkovic G \& Burgin M (Eds.), Information and computation. Hackensack, NJ: World Scientific Publishing Co.

Chalmers, D. (1996). The Conscious Mind: In Search of a Fundamental Theory. New York: Oxford University Press.

Chalmers, D. (1997). Facing up to the problem of consciousness, p. 9-32 in Shear 1997a.

Chalmers, D. (2010). The Character of Consciousness, Oxford and New York: Oxford University press.

Cobley, P. (2016): Cultural implications of biosemiotics, Biosemiotics 15, Dordrecht, Springer, publ. 
Cowley, Stephen J., Major, Joäo C., Steffensen, Sune V., Dinis, Alfredo (2010): Signifying Bodies, Biosemiosis, Interaction and Health, Braga, Portugal: The Faculty of Philosophy of Braga Portuguese Catholic University.

Davies P.C.W. (2004). John Archibald Wheeler and the clash of ideas, p. 3-23 in Barrow, J.D., Davies, P.C.W. and Harper Jr., C.L. (Eds.)(2004). Science and Ultimate Reality: Quantum Theory, Cosmology and Complexity, Cambridge: Cambridge University Press.

Davies P.C.W. (2007). Cosmic Jackpot: Why our Universe is just right for Life, Boston: Houghton Mifflin Company

Davies, P. and Gregersen, N. H. (2009)(Eds.). Information and the Nature of Reality: From Physics to Metaphysics, Cambridge: Cambridge University Press

Deacon, T. (2011). Incomplete Nature: How Mind Emerged from Matter, New York: W. W. Norton \& Company;

Deely, J. and Ashley, B. (2012). How Science Enriches Theology, Indiana. St. Augustine's Press

Dilworth, D. A. (2009). Elective Affinities: Emerson's "Poetry and Imagination" as Anticipation of Peirce's Buddhisto-Christian Metaphysics, Cognitio, São Paulo, v. 10, n. 1, p. 43-59, jan./jun.

Dodig-Crnkovic G. and Müller V. (2011), A Dialogue Concerning Two World Systems: InfoComputational vs. Mechanistic. Book chapter in: Information and Computation, Singapore:World Scientific Publishing Co. Series in Information Studies. Editors: G Dodig-Crnkovic and M Burgin, 2013

Edelmann, Gerald, M (2000). A Universe of Consciousness: How Matter becomes Imagination, New York: Basic Books

Emerson, R. W. (1883). Works of Ralph Waldo Emerson, London: George Routledge and Sons.

Emmeche, C. (1998): Defining life as a semiotic phenomenon, Cybernetics \& Human Knowing 5 (1): 3-17.

Emmeche, Claus (2004). A-life, Organism and Body: the semiotics of emergent levels. Pp. 117-124 in: Mark Bedeau, Phil Husbands, Tim Hutton, Sanjev Kumar and Hideaki Suzuki (eds.). Workshop and Tutorial Proceedings. Ninth International Conference on the Simulation and Synthesis of Living Systems (Alife IX), Boston Massachusetts, September 12th, 2004.

Esposito, J. L. (1977). Peirce and Naturphilosophie, Transaction of the Charles S. Peirce Society, 1977 Vol.13 No. 2, p. 122-141. 
Favareau, D. (Ed.) (2010).Essential Readings in Biosemiotics: Anthology and Commentary. Berlin and New York: Springer.

Faye, J.(2016). Experience and Beyond: The Outline of a Darwinian Metaphysics, New York: Palgrave Macmilan.

Goodman, R. B. (2015). American Philosophy before Pragmatism, Oxford: Oxford University Press.

Foerster . H. von(1979): "The Cybernetics of Cybernetics" in Krippendorff, K. (ed.): Communication and Control in Society. New York: Gordon and Breach Science Publishers. pp. 5-8.

Garfield, J. L (1995).The Fundamental Wisdom of the Middle Way, Oxford: Oxford university press

Geldard, R.G. (Ed.) (2005). The essential Transcendentalists, New York: Penguin

Gregersen, N. H. (2003). From Complexity to Life: On the Emergence of Life and Meaning. red. / Niels Henrik Gregersen. New York : Oxford University Press, 2003. s. 206-232.

Haack, S. (1992). Extreme Scholastic Realism: Its Relevance to Philosophy of Science Today", Transactions of the Charles S. Peirce Society, Vol. XXVIII, No. 1 (Winter, 1992), pp. 22-23.

Haack, S. and Kolenda, K. (1977). Two Fallibilists in Search of the Truth, Proceedings of the Aristotelian Society, Supplementary Volumes, Vol. 51 (1977), pp. 63-104, (Stable URL: http://www.jstor.org/stable/4106816 )

Haaparanta L. (1994). Charles Peirce and the Drawings of the Mind, Histoire Épistémologie Langage, tome 16, fascicule 1,1994. Actualité de Peirce. pp. 35-52.

Hameroff, S. (2017). "The Quantum Origin of life: How the Brain Evolved to Feel Good", in Tibayrenc, M. and Ayala, F. J.(Eds))(2017). On Human Nature,: Biology, Psychology, Ethics, Politics, and Religion, Pages 333-353, Boston: Academic Press, Elsevier.

Hankey. A. (2015). A complexity basis for phenomenology: how information states at criticality offer a new approach to understanding experience of self, being and time, Progress in Biophysics \& Molecular Biology, Volume 119, Issue 3, December.

Hartshorne, C. (1984). Towards a Buddhisto-Christian religionin K. K. Inada and N. P. Jacobson (Eds.), Buddhism and American Thinkers, pp. 1-13, (Albany: State University of New York Press).

Hartshorne, C. and W. L. Reese, (Eds.) (1953). Philosophers Speak of God, (Chicago: University of Chicago Press).

Hawking, S. and Mlodinow, L. (2010). The Grand Design, New York: Bantam Books 
Heil J. (2004). Philosophy of Mind: A Guide and Anthology. Oxford, UK: Oxford University Press. Hinde RA. (1970). Animal Behaviour: A Synthesis of Ethnology and Comparative Psychology. Tokyo, Japan: McGraw-Hill Kogakusha.

Hofkirchner, W. (2013). Emergent Information. An Outline Unified Theory of Information Framework. Singapore: World Scientific.

Hoffmeyer, J. (1996). Signs of Meaning in the Universe, trans. Haveland, B. J., Bloomington, IN: Indiana University Press.

Hoffmeyer, J. (2008). Biosemiotics: An Examination into the Signs of Life and the Life of Signs. University of Scranton Press, Scranton, PA.

Hofstadter DR. (2007). I Am a Strange Loop. New York, NY: Basic Books.

Isayeva N. (1993). Shankara and Indian philosophy. Delhi: Sri Satguru Publications.

Jackson. C. T. (1981). The Oriental Religions and American Thought: Nineteenth-Century

Explorations. Contributions in American Studies, Number 55. Westport, Conn.; London: Greenwood Press.

Jantsch, E (1980). The Self-Organizing Universe. New York: Pergamon Pres.

Kaufmann, S. (2004). Autonomous Agents, p. 654-666 in in Barrow, J.D., Davies, P.C.W. and Harper Jr., C.L. (Eds.)(2004). Science and Ultimate Reality: Quantum Theory, Cosmology and Complexity, Cambridge: Cambridge University Press.

Kauffman, S.A. (2012). From physics to semiotics, in Gatherings in Biosemiotics, Tartu: Tartu University Press, Tartu Semiotics Library.

Keeler, M. (1995). The philosophical context of Peirce's existential graphs, in Third International Conference on Conceptual Structures: Applications, Implementation and Theory, Proceedings Supplement (1995), pp. 94- 107

Kultgen, J.K. (1959-60): "The "future metaphysics" of Peirce and Whitehead", Kant-Studien 5 (195960): 285-293.

Kim, J. (2000). Mind in a Physical World: An essay on the Mind-Body problem and Mental Causation, Cambridge Massachusetts: The MIT Press.

Kim, J. (2005). Physicalism, Or Something near Enough. Princeton: Princeton University Press, 2005.

Luhmann, N. (1995). Social Systems, Stanford, CA: Stanford University Press

Luhmann, N. (1986a). The autopoiesis of social systems. In F. Geyer \& J. v. d. Zouwen (Eds.), 
Sociocybernetic Paradoxes (pp. 172-192). London: Sage.

Luhmann, N. (1996b). On the scientific context of the concept of communication.

Social Science Information, 35(2), 257-267.

Maturana, H \& Varela, F. (1980). Autopoiesis and Cognition: The realization of the Living, London Reidel

Maturana, H \& Varela, F. (1986): Tree of knowledge: Biological Roots of Human Understanding, London: Shambhala Publishers.

McGinn, C. (2000). The Mysterious Flame: Conscious Minds in a Material World, New York: Basic Books.

Merleau-Ponty, M. (1962). Phenomenology of Perception; Translated by C. Smith. Routledge \& Kegan Paul: London, UK, 2002. Originally published as Phenomenologie de la Perception; Callimard: Paris, France, 1945, English 1962.

Merleau-Ponty, M. (2003). Nature: Course Notes from the Collège de France.Illinois: North Weston University Press.

Miller, R. W. (1975). Propensity: Popper or Peirce?. British Journal for the Philosophy of Science. 26 (2): 123-132

Moravec, H._(1988). Mind Children, Cambridge MA: Harvard University Press.

Nagel, Thomas (1974). What is it like to be a bat? Philosophical review 83:435-450.

Nagel, T. (2013). Mind and Cosmos: Why the Materialist Neo-Darwinian Conception of Nature Is Almost Certainly False, Oxford: Oxford University Press.

Nicolescu, B. (2002). Manifesto of Transdisciplinarity, New York: State University of New York (SUNY) Press,

Nicolescu, B. (2014). From Modernity to Cosmodernity: Science, Culture and Spirituality, Albany, NY: State University of New York Press.

Nöth, W. (2009). On the instrumentality and semiotic agency of signs, tools, and intelligent machines, Cybernetics \& human knowing, Vol. 16, nr. 3/4 (2009), S. 11-36

Parker, K.A. (2002). "The Ascent of Soul to Noûs: Charles S. Peirce as Neoplatonist", Neoplatonism and Contemporary Thought, Part One. Ed. R. Baine Harris. Studies in Neoplatonism: Ancient and 
Modern, vol. 10. State University at New York Press, 2002. 165-182, http://agora.phi.gvsu.edu/kap/Neoplatonism/csp-plot.html visited 1. February 2007.

Peirce, B. (1881). Ideality in the Physical Sciences, Boston: Little, Brown and Company.

Peirce, C.S. (1980)(Carolyn Eisele, Ed.). NEM: The new elements of mathematics (2 Volumes), Walter De Gruyter Inc.

Peirce, C. S. (1992). Reasoning and the Logic of Things. The Cambridge Conferences Lectures of 1898, edited by K. L. Ketner, Cambridge, MA: Harvard University Press.

Peirce, C.S. (1994 [1866-1913]). The Collected Papers of Charles Sanders Peirce. Electronic edition reproducing Vols. I-VI ed. Charles Hartshorne \& Paul Weiss, Cambridge: Harvard University Press, 19311935), Vols. VII-VIII ed. Arthur W. Burks (same publisher, 1958). Charlottesville: Intelex Corporation. (CP).

Peirce, C. S. (1997). Pragmatism as a principle and method of right thinking, the 1903 Harvard Lectures on Pragmatism, Edited and introduced with a commentary by Patricia Ann Turrisi, Albany: State of New York University Press.

Peirce, C. S. (1998). The essential Peirce. Selected philosophical writings, Vol. 2 (The Peirce Edition Project, Eds.). Bloomington, IN: Indiana University Press. (EP2).

Penrose, R. (1987). The Large, the Small and the Human Mind, Cambridge: Cambridge University Press

Penrose, R. (1989): The Emperor's New Mind: Concerning Computers, Minds, and the Laws of Physics. Oxford: Oxford University Press.

Penrose, R. (1994): Shadows of the Mind: A Search for the Missing Science of Consciousness, London: Oxford University Press.

Penrose and Hameroff, S. (2011). "Consciousness in the Universe: Neuroscience, Quantum SpaceTime Geometry and Orch OR Theory”. Journal of Cosmology 14. http://journalofcosmology.com/Consciousness160.html visited 4.05.2015.

Poznanski, R. R., Tuszynski, J. A. and Feinberg, T.E.(2017). Biophysics of Consciousness: A Foundational Approach. London: World Scientific.

Prigogine, I. (1996). The End of Certainty: Time, Chaos, and the New Laws of Nature, New York: The Free Press.

Prigogine, I. and Stengers, I. (1984). Order Out of Chaos: Man's New Dialogue with Nature New York: Bantam Books. 
Ransdell, J. (1989). "Is Peirce a Phenomenologist?”. (This paper appeared in print in a French translation by André DeTienne as "Peirce est-il un phénoménologue?" in ĖtudesPhénoménologiques, 9-10 (1989), pp. 51-75. This English-language version is the original and has never been published in paper).

Ransdell, J (2011). “On Descartes’ Dualism”, http://www.libertypages.com/cgw/2011/01/21/joeransdell-on-descartes-dualism/. Posted on January 21, 2011.

Raposa, M. (1989). Peirce's Philosophy of Religion, Peirce Studies number 5, Bloomington and Indianapolis: Indiana University Press.

Richardson, R.D. (1995).Emerson: The Mind on Fire, Berkeley: University of California Press

Robertson, R. (2001). "One, two, three . . continuity: C.S. Peirce and the nature of the continuum", Cybernetics \& Human Knowing, Volume 8, Numbers 1-2, pp. 7-24(18).

Rock, A. J. 2005. Why does the Universe Exist? An Avaita Vedantic Perspective, The International Journal of Transpersonal Studies Vol. 24: 69-76.

Romanini, V. and Fernández, E. (Eds.) (2014): Peirce and Biosemiotics: A Guess at the Riddle of life, New York and London: Springer. Biosemiotics books no. 11.

Schilpp, P. A. (1941). The Philosophy of Alfred North Whitehead, Evaston and Chicago: Nortwestern University.

Schrödinger, E. (1967/1944). What is life? The physical aspect of the living cell and mind and matter, with Mind and matter, and Autobiographical Sketches, Cambridge UK: Cambridge University Press.

Searle, J. (1980). Minds, Brains, and Programs. Behavioral and Brain Sciences, 3 (3): 417-457

Searle, J. (1989): Minds, Brains and Science. London: Penguin Books.

Searle, J. (1997). The Mystery of Consciousness. NY: New York Review of Books.

Searle, J. (2007). Putting Consciousness back in the Brain. in Bennet, M., Dennet, D., Hacker, P. and Searle, J. (2007) Neuroscience \& Philosophy: Brain, Mind \& Language, New York: Columbia University Press.

Shankara, A. (1957). Eight Upanisads, vol. one, Calcutta. Advaita Ashrama.

Shankara, A. (1977). Brahma-Sutra Bhasya of Sankaracarya, Calcutta. Advaita Ashrama.

Shannon, C. 1949. "A Mathematic Theory of Communication.” In The Mathematical Theory of Communication, edited by C. E. Shannon and W. Weaver. Urbana: University of Illinois Press.

Siderits, M. and Katsura, S. (1999). Nāgārjuna's Middle Way: Mūlamadhyamakakārikāa 
Somerville, MA: Wisdom Publications.

Smolin, L. (2014). Time Reborn: From the Crisis in Physics to the Future of the Universe, New York: Mariner Books.

Stapp, H. P. (2007).The Mindful Universe: Quantum Mechanics and the Participant Observer, Berlin: Springer.

Stjernfelt, F. (2007). Diagrammatology: An Investigation in the Borderlines of Phenomenology, Ontology, and Semiotics, Dordrecht: Springer.

Stjernfelt, F. (2014). Natural Propositions: The Actuality of Peirce's Doctrine of Dicisigns. Boston : Docent Press.

Suzuki, D. T. (1963). Outlines of Mahayana Buddhism by D.T. Zuzuki, New York: Schocken Books.

Suzuki, D. T. (1969). An Introduction to Zen Buddhism, London: Random Century Group

Suzuki, D. T. (2002/1957). Mysticism: Christian and Buddhist (London: Routledge Classics).

Thompson, E. (2007). Mind in Life: Biology, Phenomenology, and the Sciences of Mind.Harvard University Press (Belknap).

Unger, R. M. and Smolin, L. (2014). The Singular universe and the Reality of Time. A proposal in Natural Philosophy, Cambridge: Cambridge University Press.

Romanini, V. and Fernández, E. (Eds.) (2014): Peirce and Biosemiotics: A Guess at the Riddle of life, New York and London: Springer. Biosemiotics books no. 11

Zelany, M. (1980). Obituary Erich Jantsch (1929-1980), Human Systems Management.

http://iospress.metapress.com/content/3422553x8j620888/fulltext.pdf, visited January 4'th 2015

Weber, Max (1920). The Protestant Ethic and "The Spirit of Capitalism" ,Translated by Stephen Kalberg (2002), Los Angeles: Roxbury Publishing Company.

Wheeler, J.A. (1990). "Information, physics, Quantum: The search for links", pp. 3-29 in W.H. Zurek (Ed.). Complexity, entropy and the physics of information. Vol. VIII in Santa Fe Institute, Studies in the Sciences of complexity. Addison Wesley publishing Company.

Wheeler J.A. (1994). At Home in the Universe, Woodbury: AIP Press

Wheeler, J.A. and Ford, K. (1998). Geons, Black Holes, and Quantum Foam, New York. W.W. Norton Company. 
Wiener, N. 1963. Cybernetics; Or, Control and Communication in the Animal and the Machine. Cambridge, MA: MIT Press.

Wolfram, S. (2002). A New Kind of Science. Champaign, IL: Wolfram Media 